\title{
Research on the Micro Class and the Applications on English Flipped Classroom Design for Application-Oriented Universities
}

\author{
Qingyun Xu \\ Jiangxi College of Engineering, \\ Xinyu,Jiangxi,338000 China
}

\begin{abstract}
In this paper, we conduct research on the micro class and general applications on English flipped classroom design for the application-oriented universities. Flip the classroom as a kind of the classroom teaching reform practice, not only does it require the participation of each a teacher, but also need level of higher vocational college English teaching and research section in the school-based teaching and research to flip the classroom teaching systematic arrangement of our school. Flip the classroom is a very conducive to promote the reform practice in higher vocational English teaching effect. Therefore, each higher vocational English teacher should be active and the current situation of scientific analysis and on this core basis, combining with their own teaching ideas put forward the corresponding strategy that will enhance the feasibility of contemporary education mode.
\end{abstract}

Keywords- Micro Class, Applications, Flipped Classroom, English, Application-Oriented, College.

\section{Introduction}

As the Chinese people to the world trade organization and China's opening to the outside world, there are both professional knowledge and high level of English compound talents will be more and more get the welcome of the society, also will be more competitive advantage. As a result, the professional English in college English teaching to cultivate the high quality, and have the ability to participate in international economic and technological competition of talents, put forward the new challenge, and at the same time, the new situation of social demand and we must change the idea of teaching, speed up the professional English teaching reform [1-3].

The formation of any a kind of teaching mode, there is no doubt that has its own theoretical basis. As for the English education, the basis could be summarized as the follows. (1) Learning is a process of decision-making. The student to the knowledge learning and using process depends on the student's decision. Decision and learning are very important for communication. If a student is considered to be a thinker, decision makers should be a student, rather than a teacher. Therefore, the teaching task and teaching activities should be to give students the opportunity to the decision-making. (2) Learning is a development process and students use their knowledge known to understand new information. How students mastery of knowledge is, therefore, is an important factor of success for study. (3) Learning is an active process. Students should not be seen as passive recipients of knowledge, and should be the active participants in the learning process. Measure, therefore, the stand or fall of teaching activities, students can not only see how much we talk or write, but to see how much they think.

Any teaching mode should be validated in the actual teaching process, teaching mode through the feedback and evaluation, adjustment and improvement. According to the theoretical review, the basic drawbacks of the contemporary English education could be summarized as the follows. (1) A serious shortage of teachers, teachers' whole quality is not high, insufficient experience in English teaching, English application practice and the English teacher 
workload is too big, in the absence of relevant professional training under the background of teaching, and is often difficult to really realize general improvement of the teaching quality. (2) Hardware level is not high, difficult to meet the needs of practical teaching. In a way, the English as a language learning, practicality is strong, the teaching hardware device is particularly important. (3) The traditional English teaching mode suitable for the small-class teaching, and under the condition of the increasing number of students can only take big class teaching and it is difficult to achieve the improvement of teaching quality, it is easy to cause the non-computer majors education situation [4-5].

Applied major social significance of the reform of personnel training is to make our school take the initiative to meet the needs of the regional economic construction and social development, and strive to develop a solid, beginning ability is strong that adapt to a wide applied talents. Accordingly, in the figure one, we show the innovative mode of English flipped classroom patter.

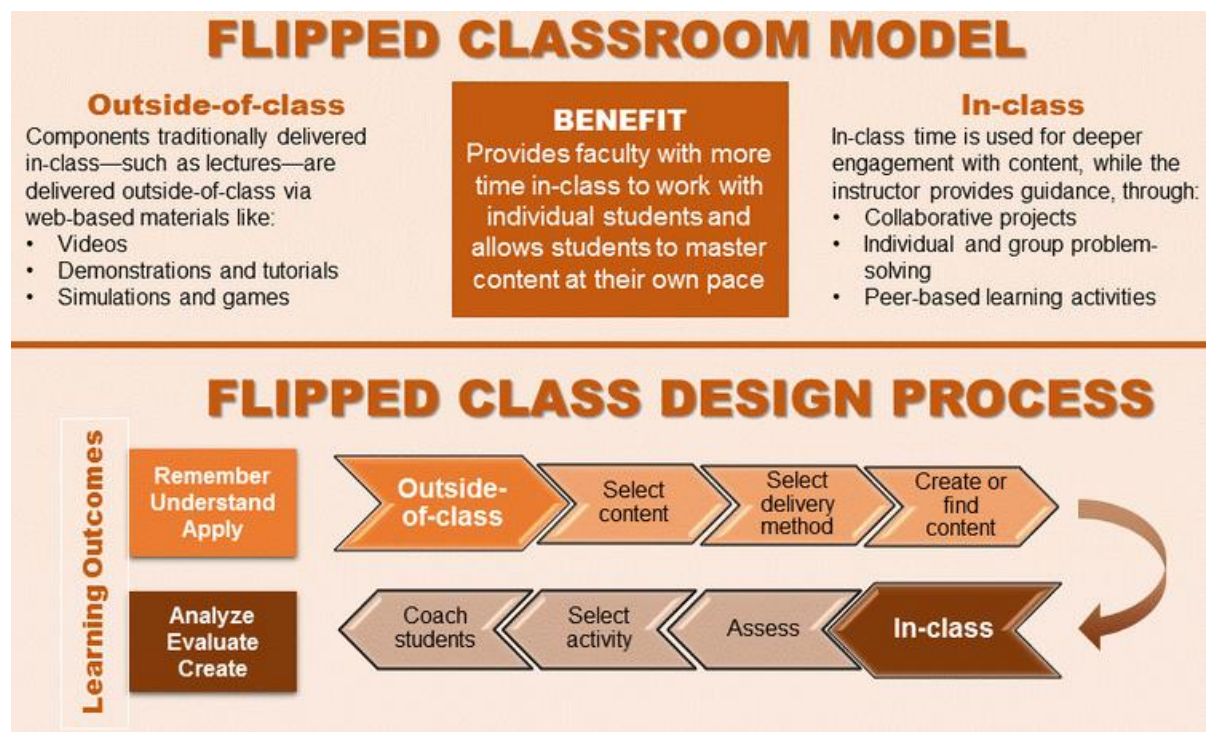

Figure 1. The Demonstration of the English Flipped Classroom Mode

In this paper, we conduct research on the micro class and general applications on English flipped classroom design for application-oriented universities. The implementation of the new era of English teaching mode inevitably touches the division of the English language ability. Whether grading type teaching, sustainable teaching mode or multimodal ecological classroom, learners and teaching in the teaching transition will pass in English ability tests to determine the next phase of the study direction. In the later sub-sections, we will conduct in-depth discussion on the related issues.

\section{Our Proposed Methodology}

The Application-Oriented Universities. The development of applied undergraduate education is to adapt to the social modernization of the objective need of the economic development as is to promote personality development and the inevitable requirement of all-round development of talents training target. China's higher education from "elite education" to "popular education", applied undergraduate education is put forward for ordinary undergraduate course colleges and universities provides a clear direction of running a school [6].

Applied talents are characterized by: engaged in practical work, strong operability, a line to 
solve practical problems in production and general management, practical application oriented knowledge conversion capability that can be applied in practice and innovation in the application. Around this characteristic, the realistic problems of the cultivation of talents in applied undergraduate colleges, the author thinks that, the main content of the reform include the follows.

- New applied undergraduate colleges and universities should adhere to professional guidance on the specialized subject construction that should take the specialized construction as the fundamental, with an emphasis on the construction of applied science, supported by discipline construction, actively explore in a professional capacity as the main line of the type of talent fostering and the hierarchy system.

- New applied undergraduate colleges and universities on the talents cultivation orientation should first reveal the vocational adaptability. Vocational adaptability refers to a person when engaged in a job must have the quality characteristics of these quality characteristics can be a certain technology, a certain skills and can also be innovation ability.

- The talent training scheme, course system, teaching contents and learning assessment should be fundamental for the general goal of talent cultivation. For a professional, four years of the curriculum is a complete system, but in the system there is fundamental and professionalism.

- Practice is the fundamental way of teaching to life, is the real capacity of the unification of basic education, to carry out the experiential teaching, such as problematic, autonomy, open education is to mobilize students to become the effective way to learn the subject.
The Flipped Classroom Characteristics. Flip the classroom is upside down imparting general knowledge transfer and absorption process of internalization of knowledge, change the roles between teachers and students in traditional teaching mode, reorganize and the lessons before class time distribution of the new teaching mode. Compared with the traditional classroom teaching mode has a certain advantage. Students cannot constrained by unified time for learning as able to independently, the flexibility to arrange study time; Can choose according to their own learning foundation suitable for their own learning courseware, and learning again and again. Increase in classroom teaching of the teacher and student, student and the student exchange. Fully embodies the teaching practice. English professional courses in English teaching in the teaching of basic theory of English teaching, English teaching law, on the basis of emphasis on teaching students how to conduct the actual teaching.

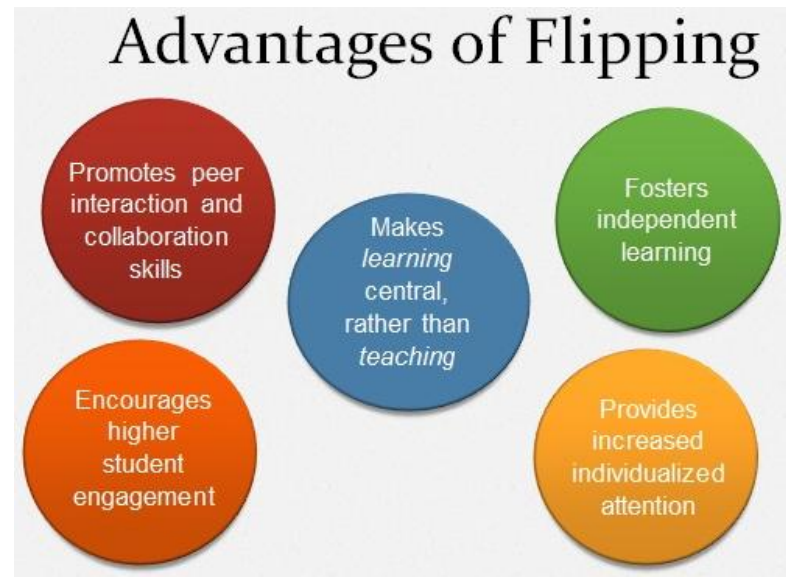

Figure 2. The Characteristics of the Flipped

Classroom Mode

Flip the classroom is able to get great success, thanks to the teaching practice of continuously, not only but also thanks to reasonable theory foundation. Flip the classroom focus on students, the zone of proximal development with difficulty the appropriate learning content exert its potential, to the level of the zone of proximal development, then on this basis for the next 
development zone development recently and in this way, we can mobilize students' learning enthusiasm. Flip the characteristics of the classroom could be generally summarized as the follows. (1) Teacher's role change. Teachers from elites to consultant, in the classroom, teachers are no longer carried to teach knowledge, but when students need guidance in a timely manner to provide targeted help. (2) The change of teaching mode. From emphasis on knowledge transfer, to the teaching mode of teaching with learning to learning as the main body, the problem centered teaching mode. (3) Flip the theoretical basis of the classroom teaching is the constructivism, the teaching view that learning process is a process of learners' active knowledge and meaning construction, students is the main character in the learning process, teachers should help students to complete the construction of knowledge and meaning [7].

In classroom teaching, students learning subjectivity is given priority to, teachers play the leading role at the same time. Teachers are no longer "cramming education", the un-riddling become the core content of the classroom teaching, terminate the student is the main task of the teacher in your heart; Teachers to help students to learn, and even a one-on-one tutoring, guides the student to complete the construction of knowledge and meaning. Practice after class, but also the teachers' leading role and students' subjectivity with the combination of the students through more difficult exercises, to further consolidate and expand the learned knowledge and stimulate students' desire to explore.

The Micro Class. Micro lesson is to interpret a certain knowledge point as the goal, in a short online video for forms, for the purpose of learning or teaching application of online teaching video. More and more educators believe that, the class is an important way in the future of mobile learning. This kind of study way change the presentation of knowledge/skills, accord with the requirement of education informationization, at the same time, enable learners to make full use of spare time to study, conforms to the spread of the Internet's demand for convenience.

Data shows that most of the teachers think: the application of micro class effect is reflected in the peer communication for reference, to promote teachers' professional development, improve the level of teachers' classroom teaching, enhance the general level of school discipline group research and school-based research, improve the efficiency of teachers' lessons is conducive to promoting regional network teaching and research level, etc. "Class" is a kind of digital teaching content, but also a novel teaching activity, it can make full use of the modern information technology and terminal equipment, convenient between students and students, learning, communication and interaction between teacher and students, to enhance the vitality of the teaching content and appeal is a new direction to promote vocational education curriculum reform that holds the following characteristics. (1) Micro is mainly used for self-study class, it's for teachers put forward more severe challenges. Before making micro class teachers, need to do adequate preparation, also want to communicate with enterprises, expert of, can't reach a higher value class. (2) A good micro class should also have their own unique bright spot. The window can be a simple story, also can be a nuanced analysis and also can be accurate and vivid language of instruction. (3) During recording of the class, the design is good teaching language, try to write a script, fastidious carefully make whether accord with the cognitive characteristics of students, how to improve the students to make it easier to understand to teach in a relatively short time.

\section{The Optimized English Education} Paradigm. The new teaching pattern should fully arouse the enthusiasm of teachers and students, especially to establish the general subject status of students in the teaching process. The change of teaching mode is not only the transformation of teaching activities or teaching means, and is the change of teaching ideas, is to 
realize the teacher-centered, simple teaching of language knowledge and the skills teaching mode, to take the student as the center, both to teach language knowledge and skills, pay more attention to language skills and autonomous learning ability of the change of teaching mode under the new media age, the use of information technology in the whole society widely, the information dissemination way more convenient, quickly, the injected new energy to the English major teaching, presents new characteristics. Under this historical period and the prior discussed theory, we propose the listed suggestions for modern education mode.

- Time increased. In the era of new media, English professional course teaching can update the teaching content, to keep pace with The Times. Through the use of new media teaching, in line with the current trend of the times and inject fresh blood for the English major teaching, to promote Chinese education internationalization trend, create beauty, intelligence and achieve for physique full scale development of a comprehensive talent [8].

- Students obtain information from the movies, pictures, etc., English learning is no longer dry, relaxed and happy learning environment quickly accept knowledge, students' own initiative improved. Students can better understand English culture, etc. to make learning English more lively, that will be the charm of English to the greatest extent.

- Practical improvement. Utilizing the new media in English teaching of professional courses, to make English teaching text, sound, more intuitive to show the application of English in real life. By the new media teaching, students can more quickly into the learning atmosphere adopt the method of interaction between teachers and students or students communicate with each other and improve the students' learning efficiency.

\section{Conclusion}

In this paper, we conduct research on the micro class and the general applications on English flipped classroom design for application-oriented universities. Flip the classroom teaching is a very beneficial to promote the teaching reform of the higher vocational English teaching effects in practice and the promotion of the research of the strategy about the present situation of its practice, both is helpful to improve the teaching ability of teachers, and to promote the teaching reform of our school. Therefore, this article intends to turn in interpreting the connotation of classroom, turn to the current higher vocational English classroom teaching objective of the present status and put forward corresponding promotion strategy for the general teacher reference. In the future research, we will integrate more of related theories concerning about enhancing education efficiency to optimize our current method.

\section{References}

[1] Piotrowski, Amy, and Shelbie Witte. "Preservice English Teachers Use Technology to Flip the Classroom." Proceedings of Global Learn 2015 (2015): 487-491.

[2] Zhang, Weiran, Rongxia Wang, and Jinjun Chen. "Flipped Classroom Model Based Instruction of College English in ICT Environment." (2015).

[3] Huang, Yu-Ning, and Zuway-R. Hong. "The effects of a flipped English classroom intervention on students' information and communication technology and English reading comprehension." Educational Technology Research and Development (2015): 1-19. 
[4] Abeysekera, Lakmal, and Phillip Dawson. "Motivation and cognitive load in the flipped classroom: definition, rationale and a call for research." Higher Education Research \& Development 34.1 (2015): 1-14.

[5] Flynn, Alison B. "Structure and evaluation of flipped chemistry courses: organic \& spectroscopy, large and small, first to third year, English and French." Chemistry Education Research and Practice 16.2 (2015): 198-211.

[6] Szafir, Daniel, and Bilge Mutlu. "ARTFul: adaptive review technology for flipped learning." Proceedings of the SIGCHI Conference on Human Factors in Computing Systems. ACM, 2013.

[7] FAN, Linxiu, Huifang ZENG, and Lixia LI. "Research on" Flipped Classroom" Teaching Mode of Introduction to College Information Technology." Journal of Gannan Normal University 3 (2014).

[8] WANG, Su-min, and Li-xin ZHANG. "A Study of College EFL Learners' Acceptance Towards Flipped Classroom." Modern Educational Technology 3 (2014): 011. 